\title{
Penerapan Pembelajaran Jigsaw Berbantuan Media Puzzle Untuk Meningkatkan Aktivitas Dan Hasil Belajar IPS Siswa Di Kecamatan Tallo Kota Makassar
}

\section{The Implementation of Puzzle-based Jigsaw Learning to Improve the Social Studies Learning Activities and Outcomes of Students at Tallo District, Makassar City}

\author{
Asmi Aminuddin ${ }^{1 *}$, Muhammad Yunus ${ }^{2}$, Sundari Hamid ${ }^{2}$ \\ ${ }^{1}$ Sekolah Dasar Inpres Galangan Kapal II Kota Makassar \\ ${ }^{2}$ Program Studi Pendidikan Dasar, Program Pascasarjana, Universitas Bosowa \\ *E-mail: asmiaminuddin@gmail.com
}

Diterima: 10 September 2021/Disetujui 23 Desember 2021

\begin{abstract}
Abstrak. Penelitian ini bertujuan untuk mengetahui peningkatan hasil belajar dengan penerapan pembelajaran jigsaw berbantuan media puzzle pada mata pelajaran IPS siswa di Kecamatan Tallo Kota Makassar. Jenis penelitian ini adalah penelitian eksperimen semu (quasi eksperimen). Instrumen pengumpulan data yang digunakan adalah observasi dan tes. Teknik analisis data yang digunakan adalah analisis deskriptif kuantitatif. Populasi dalam penelitian ini adalah siswa SD kelas V di SD Inpres Kecamatan Tallo Kota Makassar. Sampel penelitian ini berjumlah 50 orang siswa yang dibagi menjadi dua kelompok yaitu kelompok eksperimen dan kelompok kontrol dengan masing-masing kelompok terdiri atas 25 orang siswa SD Inpres Galangan Kapal II dan 25 orang siswa SD Inpres Galangan Kapal IV Kota Makassar. Hasil penelitian menunjukkan terdapat peningkatan aktivitas dan hasil belajar dalam penerapan pembelajaran jigsaw berbantuan media Puzzle pada mata pelajaran IPS terhadap siswa di Kecamatan Tallo Kota Makassar sebesar 92\%. Kegiatan pembelajaran dengan penerapan model pembelajaran jigsaw, selain dapat meningkatkan pemahaman siswa pada materi pelajaran juga dapat dijadikan sebagai sarana untuk memupuk rasa persatuan, memperlancar komunikasi, membentuk sifat yang tidak egois, dan memupuk rasa tanggung jawab siswa baik dalam kelompok maupun individual.
\end{abstract}

Kata Kunci: IPS, Pembelajaran Jigsaw, Media Puzzle

Abstract. The objective of this research is to know the improvement of learning outcomes using the application of jigsaw learning model by puzzle media in social studies of the students in Tallo District, Makassar City. This study is quasi experimental research. The data collection instrument used observation and test. The data analysis technique used quantitative descriptive analysis. The population in this study were fourth grade elementary school students at Inpres Elementary Schools, Tallo District, Makassar City. The sample of this study is 50 students who were divided into two groups, namely the experimental group and the control group with each group consisting of 25 students of SD Inpres Galangan Kapal II and 25 students of SD Inpres Galangan Kapal IV Makassar City. The result showed that there was the improvement in learning activities and outcomes using the application of jigsaw learning model by puzzle media in social science of the students in Tallo District, Makassar City which was 92\%. The learning activities using the application of learning model of jigsaw can improve the students' understanding of learning materials. It can also be used as a mean to increase unity, facilitate communication, forming an unselfish nature, and increase the students' responsibility both in group and individual.

Keywords: Social Science, Learning Model Of Jigsaw, Puzzle Media

This work is licensed under Creative Commons Attribution License 4.0 CC-BY International license

\section{Pendahuluan}

Ilmu pengetahuan sosial, yang sering disingkat dengan IPS, adalah ilmu pengetahuan yang mengkaji berbagai disiplin ilmu sosial dan humaniora serta kegiatan dasar manusia yang dikemas secara ilmiah dalam rangka memberi wawasan dan pemahaman yang mendalam kepada peserta didik, khususnya ditingkat dasar dan menengah (Susanto, 2014).

IPS merupakan salah satu mata pelajaran yang diajarkan di Sekolah Dasar. Permendikbud No. 64 tahun 2013 tentang standar isi satuan pendidikan dasar dan menengah bahwa ilmu pengetahuan sosial merupakan muatan pembelajaran yang diberikan mulai dari SD/MI/SDLB sampai SMP/MTS/SMPLBB. Ilmu Pengetahuan Sosial merupakan salah satu muatan yang berusaha memberikan wawasan secara komprehensif tentang peristiwa, fakta, konsep, dan generalisasi yang berkaitan dengan isu-isu sosial, tradisi dalam ilmu sosial yang dikemas secara pedagogik, integratif, dan komunikatif secara relevan dengan situasi dan kondisi yang berkembang dalam masyarakat (Supardi, 2011). Beberapa objek kajian dalam pembelajaran IPS di SD dapat menyebabkan siswa kesulitan dalam memahami materi tersebut (Supriatna, 2009)

Model pembelajaran yang tepat dalam proses mengajar dapat menarik minat dan motivasi peserta didik untuk belajar, untuk itu perlu ada usaha-usaha dari semua pihak terutama guru dan peserta didik dalam mewujudkannya. Dengan 
kata lain, persoalan belajar sebagai kegiatan yang akan dikembangkan, tidak dapat dipisahkan dengan pemaknaan hakikat hidup manusia baik yang belajar maupun yang membelajarkan. Secara tersirat persoalan-persoalan itu mestinya menjadi rujukan dalam membahas masalah-masalah hasil belajar.

Salah satu model pembelajaran kooperatif yang bisa melibatkan siswa secara aktif adalah tipe jigsaw. Pembelajaran kooperatif tipe jigsaw merupakan salah satu tipe strategi pembelajaran yang kooperatif dan fleksibel (Lie. 2010). Dalam pembelajaran tipe jigsaw, siswa dibagi menjadi kelompok-kelompok yang anggotanya mempunyai karakteristik heterogen. Masing-masing siswa bertanggung jawab untuk mempelajari topik yang ditugaskan dan mengajarkan pada anggota kelompoknya, sehingga mereka dapat saling berinteraksi dan saling bantu (Adhi et al. 2013)

Media merupakan salah satu komponen yang tidak bisa diabaikan dalam pengembangan sistem pengajaran yang sukses. Menurut Djamarah dan Aswan Sain (2010: 12) media adalah alat bantu apa saja yang dapat dijadikan sebagai penyalur pesan guna mencapai tujuan pengajaran.

Situmorang dalam Husna, dkk. (2017) puzzle adalah sejenis permainan yang berupa potongan-potongan gambar yang cara bermainnya yaitu dengan menyusunnya sehingga terbentuk sebuah gambar, dengan tujuan untuk melatih kesabaran, memudahkan peserta didik dalam memahami konsep, memecahkan masalah, saling bekerja sama dengan teman, serta mengembangkan keterampilan motorik dan kognitif peserta didik. Hal ini sesuai dengan pernyataan Jamil (2016) puzzle dapat meningkatkan kemampuan bekerja sama kelompok, meningkatkan kemampuan anak mengenali suatu bentuk, melatih dan meningkatkan daya analisis anak terhadap suatu masalah.

Belajar adalah key terms (istilah kunci) yang paling vital dalam usaha pendidikan, sehingga tanpa belajar sesungguhnya tidak pernah adanya pendidikan. Secara kuantitatif belajar adalah kegiatan pengisian atau pengembangan kemampuan kognitif dengan fakta sebanyak-banyaknya. Jadibelajar dalam hal ini dipandang dari sudut banyaknya materi yang dikuasai oleh siswa.

Siswa yang lebih banyak aktif dalam melakukan kegiatan dalam proses pembelajaran sedangkan guru lebih banyak sebagai motivator dan membimbing dan mengarahkan siswa (Puspita et al 2021). Siswa dapat mengembangkan berpikir kritis dan dapat mengalami sendiri sehingga proses pembelajaran hidup karena siswa terlibat secara langsung. Tanpa adanya aktivitas, proses belajar mengajar tidak dapat berlangsung dengan baik, karena pada prinsipnya belajar adalah berbuat, dan setiap orang yang belajar harus aktif. Jadi, aktivitas juga berperan dalam menentukan keberhasilan belajar mengajar.

Hasil belajar merupakan hasil dari suatu interaksi tindak belajar dan tindakmengajar Dari sisi guru, tindak mengajar akan diakhiri dengan proses evaluasi hasil belajar. Dari sisi siswa, hasil belajar merupakan berakhirnya puncak proses belajar. Hasil belajar, untuk sebagian adalah berkat tindak guru, suatu pencapaian tujuan pengajaran. Dan pada bagian lain, merupakan peningkatan kemampuan mental siswa (Dimyati dan Mudjiono, 2006).

Terdapat berbagai kendala yang terjadi di kelas terkait dengan proses pembelajaran IPS. Pada saat peneliti melakukan observasi di kelas V SD Inpres Galangan Kapal IV, guru terlihat sedang memaparkan materi dengan menggunakan metode konvensional yaitu ceramah dan siswa hanya mendengarkan (teacher center). Terlihat kejenuhan dan kebosanan dari ekspresi siswa. Sedangkan berdasarkan wawancara yang dilakukan kepada siswa, dapat disimpulkan bahwa menurut siswa pembelajaran IPS bukan merupakan pelajaran yang sulit hanya saja banyak materi yang terdapat pada pelajaran IPS terbilang banyak terutama pada materi bacaan yang banyak, sehingga membuat siswa merasa kesulitan untuk mengingatnya dan mereka menganggap bahwa pembelajaran IPS tidak menyenangkan. Proses belajar mengajar yang pasif dalam menerima materi pembelajaran yang berdampak pada hasil belajar siswa.

Pemilihan model dan media pembelajaran ini harus disesuaikan dengan mata pelajaran yang diajarkan dan juga standar kompetensi yang disampaikan, selain memperhatikan sarana dan prasarana yang ada dan kondisi serta situasi siswa (Puspita et al. 2021). Dalam proses pembelajaran pemilihan model dan media pembelajaran yang tepat akan mempengaruhi peningkatan aktivitas belajar dan hasil belajar siswa yang maksimal. Oleh karena itu, demi efektifnya pembelajaran IPS guna meningkatkan aktivitas dan hasil belajar siswa, maka sangat diperlukan kemampuan guru dalam pembelajaran, dan menumbuhkan motivasi belajar siswa mengikuti proses pembelajaran melalui penerapan pembelajaran jigsaw berbantuan media puzzle.

\section{Metode Penelitian}

\section{a) Jenis Penelitian}

Jenis penelitian yang digunakan dalam penelitian ini adalah penelitianeksperimen semu (quasi eksperimen). Peneliti menggunakan pendekatan penelitian kuantitatif.

b) Lokasi dan Waktu Penelitian

Lokasi penelitian SD Inpres Galangan Kapal II dan SD Inpres Galangan Kapal IV Kecamatan Tallo Kota Makassar. Penelitian ini dilaksanakan pada bulan April-Mei 2021 semester genap tahun pelajaran 2020/2021.

\section{c) Populasi dan Sampel}

1) Populasi

Populasi dalam penelitian ini adalah siswa Sekolah Dasar di Kecamatan Tallo Kota makassar.

\section{2) Sampel}

Penelitian ini menggunakan teknik sampling. Teknik sampling yang digunakan adalah Random Sampling. Dimana teknik ini dipilih berdasarkan nilai probabilitas dan pemilihannya dilakukan secara acak. Adapun 
sampel dalam penelitian ini adalah, siswa kelas V SD Inpres Galangan Kapal II dan SD Inpres Galangan Kapal IV Kota Makassar Sampel terdiri atas 25 orang siswa SD Inpres Galangan Kapal II dan 25 siswa SD Inpres Galangan Kapal IV Kota Makassar.

\section{d) Variabel Penelitian}

Dalam penelitian ini yang menjadi dependen variable atau variabel bebas yaitu aktivitas dan hasil belajar IPS Siswa. Sedangkan independen variable atau variabel terikat merupakan variabel yang mempengaruhi atau yang menjadi sebab. Dalam penelitian ini yang menjadi independen variable atau variabel terikat adalah penerapan pembelajaran jigsaw berbantuan media puzzle.

\section{e) Instrument Penelitian}

1. Metode Observasi (pengamatan)

Pedoman observasi yang digunakan peneliti ketika mengumpulkan data melalui pengamatan dan pencatatan secara sistematis terhadap fenomena yang diselidiki.

2. Metode Dokumentasi

Pedoman dokumentasi yang digunakan peneliti ketika mengumpulkan data yaitu alat bantu berupa kamera digital dan alat perekam.

3. Metode Tes

Dalam penelitian ini, peneliti menggunakan instrument tes. Tes yang digunakan pada penelitian ini berbentuk tes pilihan ganda dengan jumlah soal sebanyak 20 nomor.

\section{f) Teknik Pengumpulan Data}

Teknik pengumpulan data yang dilakukan dengan metode tes dan observasi (pengamatan).

\section{g) Teknik Analisis Data}

1. Membuat tabulasi skor siswa

2. Menghitung persentase kemampuan siswa

3. Analisis statistika inferensial

Analisis statistika inferensial digunakan untuk menguji hipotesis penelitian dengan menggunakan uji-t, sebelumnya dilakukan pengujian normalitas terlebih dahulu dilakukan sebelum menguji hipotesis yang telah dilakukan sebelumnya.

Pengujian normalitas yang digunakan adalah kolmogorow-smirnow untuk mengetahui data yang mengikuti populasi berdistribusi normal atau tidak. Kriteria yang digunakan adalah data hasil belajar dikatakan mengikuti populasi yang berdistribusi normal jika nilai p-value $>\alpha=0,05$.

Pengujian hipotesis dimaksudkan untuk menjawab hipotesis penelitian yang telah diajukan maka pengujian dilakukan dengan menggunakan uji-t. Uji hipotesis tersebut dilakukan dengan uji t-test Equality of Means menggunakan program SPSS 16 for windows dengan nilai $\alpha$ adalah 0,05 . Hipotesis nol ditolak dan kerja diterima jika nilai sig $<\alpha$. Sedangkan hipotesis nol diterima dan hipotesis kerja diterima jika nilai sig $>\alpha$.

\section{Hasil dan Pembahasan}

\section{a. Hasil Analisis Data}

\section{Hasil Analisis Deskriptif}

Analisis deskriptif data digunakan untuk mendapatkan gambaran umum data penelitian. Analisis deskriptif meliputi; total nilai, rata-rata, nilai maksimal, nilai minimum dan simpangan baku. Analisis deskriptif data hasil belajar kelas eksperimen dan kelas kontrol dapat dilihat berikut ini:

a. Hasil Pretest di kelas eksperimen atau kelas V SD Inpres Galangan Kapal IV diperoleh total nilai sebesar 1280 dengan nilai terkecil sebesar 45 dan nilai terbesar sebesar 75 memiliki rata-rata sebesar 57.20 dan simpangan baku sebesar 9.691

b. Hasil Posttest di kelas eksperimen atau kelas V SD Inpres Galangan Kapal IV diperoleh total nilai sebesar 2170 dengan nilai terkecil sebesar 75 dan nilai terbesar sebesar 100 memiliki rata-rata sebesar 86.80 dan simpangan baku sebesar 7.483

c. Hasil Pretest di kelas kontrol atau kelas V SD Inpres Galangan Kapal II diperoleh total nilai sebesar 1105 dengan nilai terkecil sebesar 35 dan nilai terbesar sebesar 60 memiliki rata-rata sebesar 44.20 dan simpangan baku sebesar 7.171

d. Hasil Pretest di kelas kontrol atau kelas V SD Inpres Galangan Kapal II diperoleh total nilai sebesar 1875 dengan nilai terkecil sebesar 55 dan nilai terbesar sebesar 85 memiliki rata-rata sebesar 75.00 dan simpangan baku sebesar 7.500

\section{Hasil Uji Normalitas}

Uji normalitas dilakukan untuk menguji apakah variabel berdistribusi normal atau tidak. Uji normalitas menggunakan rumus Kolmogorov-Smirnov dalam perhitungan menggunakan program SPSS 16.00. Untuk mengetahui normal tidaknya adalah jika sig $>0.05$ maka normal dan jika sig < 0.05 dapat dikatakan tidak normal. Hasil perhitungan yang diperoleh sebagai berikut: 
Tabel 1. Hasil Uji Normalitas

\begin{tabular}{cccc}
\hline No & Kelompok & Sig. & Kesimpulan \\
\hline 1 & Pretest kelas eksperimen & 1.056 & Normal \\
2 & Posttest kelas eksperimen & 0.891 & Normal \\
3 & Pretest kelas control & 1.205 & Normal \\
4 & Posttest kelas control & 1.300 & Normal \\
\hline
\end{tabular}

Berdasarkan tabel di atas, terlihat bahwa data pretest dan posttest hasil belajar baik kelas eksperimen maupun kelas kontrol memiliki nilai signifikansi yang lebih besar dari nilai 0.05, maka dapat disimpulkan kelompok data tersebut berdistribusi normal.

\section{Hasil Uji t Kelas Eksperimen dan Kelas Kontrol}

Uji t-test one sampel digunakan untuk mengetahui apakah terdapat perbedaan aktivitas belajar dua sampel (dua kelompok) yang berpasangan atau berhubungan. Uji t-tes one sampel merupakan bagian dari statistik parametrik, oleh karena itu sebagaimana aturan dalam statistik parametrik data penelitian haruslah berdistribusi normal.

Tabel 2. Hasil Uji t Kelas Eksprimen dan Kelas Kontrol

\begin{tabular}{ccc}
\hline Kelas & $\mathrm{t}$ & Sig. (2-tailed) \\
\hline Kelas Eksperimen & 57.99 & 0.000 \\
Kelas Kontrol & 50.00 & 0.000 \\
\hline
\end{tabular}

Berdasarkan Tabel 2. di atas, diperoleh nilai t kelas eksperimen atau kelas V SD Inpres Galangan Kapal IV sebesar 57.99 lebih tinggi dibandingkan nilai t pada kelas kontrol atau kelas V SD Inpres Galangan Kapal II sebesar 50.00, sehingga dapat disimpulkan bahwa Penerapan pembelajaran jigsaw berbantuan media puzzle pada aktivitas belajar mata pelajaran IPS terhadap siswa di Kecamatan Tallo Kota Makassar terlaksana dengan baik.

4. Distribusi Frekuensi Pretest dan Posttest Kelas Eksperimen

Distribusi frekuensi skor pretest kelas eksperimen dapat dilihat dari tabel berikut ini:

Tabel 3. Distribusi Frekuensi Pretest dan Posttest Kelas Eksperimen

\begin{tabular}{lcccc}
\hline No & Kategori & KKM & Frekuensi & Persentase \\
\hline 1 & Baik & $>75$ & 0 & $0 \%$ \\
2 & Cukup & 75 & 4 & $16 \%$ \\
3 & Kurang & $<75$ & 21 & $84 \%$ \\
\hline & Jumlah & & $\mathbf{2 5}$ & $\mathbf{1 0 0 \%}$
\end{tabular}

Berdasarkan tabel di atas, frekuensi pretest kelas eksperimen terbanyak mendapatkan nilai kurang dari 75 sebesar 21 orang atau 84\%. Setelah diterapkan pembelajaran jigsaw berbantuan media puzzle pada aktivitas belajar maka diperoleh distribusi frekuensi skor posttest kelas eksperimen dapat dilihat sebagai berikut:

Tabel 4. Distribusi Frekuensi Skor Posttest Kelas Eksperimen

\begin{tabular}{lcccc}
\hline No & Kategori & KKM & Frekuensi & Persentase \\
\hline 1 & Baik & $>75$ & 23 & $92 \%$ \\
2 & Cukup & 75 & 2 & $18 \%$ \\
3 & Kurang & $<75$ & 0 & $0 \%$ \\
\hline & Jumlah & & $\mathbf{2 5}$ & $\mathbf{1 0 0 \%}$ \\
\hline
\end{tabular}

Berdasarkan Tabel 4. di atas, frekuensi posttest kelas eksperimen terbanyak mendapatkan nilai lebih dari 75 sebesar 23 orang atau 92\%. Maka dapat ditarik kesimpulan bahwa Terdapat peningkatan hasil belajar dalam penerapan pembelajaran jigsaw berbantuan media Puzzle pada mata pelajaran IPS terhadap siswa di Kecamatan Tallo Kota Makassar.

\section{b. Pembahasan Hasil Penelitian}

Pertemuan I, guru mengamati kondisi siswa untuk siap diberikan pretest materi pembelajaran peran ekonomi dalam upaya menyejahterakan kehidupan masyarakat di bidang sosial dan budaya untuk memperkuat kesatuan dan persatuan bangsa. Setelah diberikan pretest, rata-rata nilai yang diperoleh siswa tidak mencapai KKM yaitu 60 sehingga peneliti menerapkan model pembelajaran jigsaw berbantuan media puzzle materi pembelajaran peran ekonomi dalam upaya menyejahterakan kehidupan masyarakat di bidang sosial dan budaya untuk memperkuat kesatuan dan persatuan bangsa di kelas V SD Inpres Galangan Kapal IV.

Kegiatan awal pembelajaran Jigsaw dimulai dengan guru memberikan motivasi untuk membangkitkan minat siswa belajar di kelas, kemudian guru mulai menggali pengetahuan awal siswa terkait materi pembelajaran dan memberikan apersepsi. Selanjutnya guru menjelaskan tujuan pembelajaran yang akan dicapai dan menjelaskan cakupan materi pembelajaran. 
Selanjutnya guru membagi kelas menjadi 5 kelompok asal. Kemudian dengan bantuan guru masing-masing kelompok asal membagi diri menjadi kelompok ahli. Setiap kelompok diberikan materi yang sama. Setiap kelompok diberikan sebuah contoh dan sebuah puzzel kemudian siswa diminta untuk mencari gambar pada puzzel, siswa juga menjawab pertanyaan yang dibagikan setiap kelompok dengan cara berdiskusi. Selama siswa melakukan kegiatan diskusi dengan kelompoknya guru berkeliling kelas melihat aktivitas yang dilakukan oleh siswa.

Apabila siswa mengalami kesulitan, guru akan membantu dan membimbing siswa. Setelah kegiatan diskusi selesai, masing-masing perwakilan dari tiap kelompok maju ke depan kelas untuk melaksanakan presentasi dalam sidang pleno. Kelompok 1 mempresentasikan hasil diskusinya kemudian 4 kelompok menanggapinya. Langkah yang terakhir adalah guru menanggapi hasil diskusi siswa kemudian bersama dengan guru siswa membuat kesimpulan.

Pada pertemuan I, sebagian siswa mengalami kebingungan karena belum terbiasa. Dalam penerapan model pembelajaran jigsaw, siswa dituntut lebih aktif, dibiasakan dapat bekerja sama dalam kelompoknya, mandiri, mau berbagi dengan teman, berani tampil ke depan dan kreatif. Hal-hal yang seperti ini merupakan pengalaman yang baru bagi siswa, karena biasanya siswa hanya duduk tenang, mendengar, mencatat dan kadang menghafal yang dilakukan sambil mengantuk. Kebiasaan buruk tersebut pada pertemuan I masih melekat pada sebagian besar siswa.

Pertemuan selanjutnya yaitu pertemuan II, guru mengingatkan kembali materi yang telah diajarkan pada pertemuan sebelumnya. Setelah itu siswa kembali ke kelompok asal, Guru kembali membagikan subtopik kepada masing-masing kelompok dan meminta perwakilan dari tiap kelompok untuk membaca topik tersebut. Guru kemudian membagikan sebuah puzzle ke kelompok dan meminta siswa untuk menyusun puzzle tersebut dan berdiskusi tentang topik yang ditemukan dalam puzzle. Setelah menemukan gambar pada puzzle siswa menyampaikan hasil diskusi di depan kelas, guru juga memberikan reward kepada kelompok yang berani dan menyampaikan hasil diskusi dengan baik. Guru menanggapi hasil diskusi siswa dan pernyataan dari beberapa siswa tentang materi pembelajaran, kemudian siswa bersama dengan guru membuat kesimpulan. Kelas ditutup dengan pemberian posttest.

Berdasarkan observasi dan hasil uji-t diperoleh nilai t kelas eksperimen atau kelas V SD Inpres Galangan Kapal IV sebesar 57.99 lebih tinggi dibandingkan nilai t pada kelas kontrol atau kelas V SD Inpres Galangan Kapal II sebesar 50.00, sehingga dapat disimpulkan bahwa Penerapan pembelajaran jigsaw berbantuan media puzzle pada aktivitas belajar mata pelajaran IPS terhadap siswa di Kecamatan Tallo Kota Makassar terlaksana dengan baik.

Setelah siswa mengenal dan memahami pembelajaran jigsaw, sedikit demi sedikit sikap negatif siswa yang terbiasa dengan pembelajaran konvensional mulai berkurang. Sikap negatif tersebut diantaranya tidak dapat bekerja sama, egois, mengganggu teman, bergurau, mengantuk, tidak percaya diri yang ditujukan dalam hal tidak berani bertanya, mengemukakan pendapat dan tampil di depan teman-temannya untuk mempresentasikan hasil kerjanya.

Dengan berkurangnya sikap-sikap negatif siswa, kegiatan pembelajaran peran ekonomi dalam upaya menyejahterakan kehidupan masyarakat di bidang sosial dan budaya untuk memperkuat kesatuan dan persatuan bangsa pada pertemuan II berjalan semakin baik, kondusif dan dinamis. Meningkatnya pemahaman siswa maka meningkatkan aktivitas siswa dalam belajar sehingga berpengaruh pada peningkatan hasil belajar yang diperoleh melalui tes akhir (posttest).

Berdasarkan observasi dan hasil uji persentase, terdapat kenaikan rata-rata kelas eksperimen dimana pada saat tes awal (pretest) diperoleh hasil belajar rata-rata siswa kelas V SD Inpres Galangan Kapal IV dalam kategori kurang sebanyak 21 siswa (84\%). Setelah penerapan pembelajaran jigsaw berbantuan media puzzle dan dilakukan tes akhir (posttest) diperoleh hasil belajar rata-rata siswa kelas V SD Inpres Galangan Kapal IV dalam kategori baik sebanyak 23 siswa (92\%). Dengan jumlah siswa yang tuntas belajar di pertemuan I sebanyak 4 orang (16\%) dan pertemuan II sebanyak 25 orang (100\%).

Berdasarkan hasil penerapan pembelajaran jigsaw berbantuan media puzzle di kelas eksperimen terjadi peningkatan hasil belajar terhadap siswa kelas V pada mata pelajaran IPS sebesar 92\%. Beberapa faktor yang mendukung keberhasilan kegiatan pembelajaran jigsaw ditandai dengan aktivitas belajar siswa dan perolehan hasil tes yang meningkat disebabkan oleh peningkatan pemahaman siswa pada materi peran ekonomi dalam upaya menyejahterakan kehidupan masyarakat di bidang sosial dan budaya untuk memperkuat kesatuan dan persatuan bangsa dan kegiatan belajar yang tampak hidup dan semangat karena siswa aktif dan termotivasi untuk belajar serta partisipasi siswa dalam kelompok.

Kegiatan pembelajaran dengan penerapan model pembelajaran jigsaw, selain dapat meningkatkan pemahaman siswa pada materi pelajaran yang ditandai dengan hasil belajar yang meningkat, juga dapat dijadikan sebagai sarana untuk memupuk rasa persatuan, memperlancar komunikasi, membentuk sifat yang tidak egois dan memupuk rasa tanggung jawab siswa baik dalam kelompok maupun individual. Dengan demikian, beban guru menjadi berkurang dan aktivitas siswa semakin menonjol.

\section{Kesimpulan dan Saran}

Penerapan pembelajaran jigsaw berbantuan media puzzle terbukti dapat meningkatkan hasil belajar pada mata pelajaran IPS siswa dalam kelompok eksperimen. Berdasarkan hasil penerapan pembelajaran jigsaw berbantuan media puzzle dapat meningkatkan aktivitas belajar pada mata pelajaran IPS siswa dalam kelompok eksperimen. Guru dapat melakukan hal yang sama pada mata pelajaran lain yaitu dengan menggunakan model pembelajaran jigsaw dengan mengembangkan berbagai bentuk kegiatan di dalamnya agar pembelajaran jadi lebih menarik. Peran guru dalam model pembelajaran jigsaw sebagai fasilitator sangat diperlukan selama pembelajaran berlangsung. Untuk itu guru sebaiknya lebih memperhatikan aktivitas siswa agar pembelajaran berjalan efektif. Keaktifan siswa pada pembelajaran akan berpengaruh pada situasi kelas, sehingga siswa diharapkan agar aktif selama pembelajaran dan diskusi berlangsung. 


\section{Daftar Pustaka}

Adhi, I.A. Puspa, dkk. 2013. Pengaruh Pendekatan Kooperatif Tipe Jigsaw Dalam Pembelajaran Bahasa Inggris Terhadap Prestasi Belajar Menulis Ditinjau Dari Bakat Verbal Siswa SMP Negeri 2 Amlapura. e-Journal Program Pascasarjana Universitas Pendidikan Ganesha. Vol. 4.

Asis, Bustaman. 2013. Meningkatkan Hasil Belajar IPS dengan Menggunakan Model Pembelajaran Kooperatif Tipe Jigsaw pada Siswa Kelas IV SDN 1 Gimpubia. Jurnal Dikdas. Vol. 1 No.3.

Arsyad, Azhar. 2014. Media Pembelajaran. Jakarta: PT Raja Grafindo Persada. Aunurrahman. 2009. Belajar dan Pembelajaran. Bandung: Alfabeta .

Dimyati dan Mujiono, 2006. Belajar dan Pembelajaran. Jakarta: Rineka Cipta.

Djamarah, Syaiful Bahri dan Aswan Zain. 2010. Strategi Belajar Mengajar. Jakarta: Rineka Cipta.

Gunawan, R. 2013. Pendidikan IPS Filosofi, Konsep dan Aplikasi. Bandung: Alfabeta.

Hertiavi, M.A., dkk. 2010. Penerapan Model Pembelajaran Kooperatif Tipe Jigsaw Untuk Peningkatan Kemampuan Pemecahan Masalah Siswa SMP. Jurnal Pendidikan Fisika. Vol.6 No.1.

Huda, Miftahul. 2015. Model-Model Pengajaran dan Pembelajaran. Yogyakarta: Pustaka Belajar.

Husna, Nurul, dkk. 2017. Pengembangan Media Puzzle Materi Pencemaran Lingkungan di SMP Negeri 4 Banda Aceh. Jurnal Pendidikan Sains Indonesia. 5 (1): 66-71

Jamil, Sya'ban. 2016. Permainan Cerdas dan Kreatif. Jakarta: Penebar Plus.

Lie, Anita. 2010. Cooperative Learning: Mempraktekkan Cooperative Learning Di Ruang-Ruang Kelas. Jakarta: Grasindo Widia Sarana Indonesia.

Maryati, dkk. 2014. Penerapan Metode Jigsaw Untuk Meningkatkan Hasil Belajar Siswa Kelas IV Pada Mata Pelajaran IPS di SDK Despot Petunasugi Kecamatan Bolano Lambunu. Jurnal Kreatif Tadulako Online.Vol. 4 No.5.

Rosyidah, Ummi. 2016. Pengaruh Model Pembelajaran Kooperatif Tipe Jigsaw Terhadap Hasil Belajar Matematika Siswa Kelas VIII SMP Negeri 6 Metro. Jurnal SAP. Vol. 1 No. 2.

Rusman. 2011. Model-Model Pembelajaran Mengembangkan Profesionalisme Guru. Jakarta: Raja Grafindo Persada.

Sadiman, Arief S., dkk. 2014. Media Pendidikan: Pengertian, Pengembangan dan Pemanfaatannya. Jakarta: PT. Raja Grafindo. Persada

Sudjana, Nana. 2013. Dasar-dasar Proses Belajar Mengajar. Bandung: SinarBaru Algensindo.

Sugiyono. 2009. Metode Penelitian Kuantitatif, Kualitatif dan R\&D. Bandung:Alfabeta.

Sumiati dan Asra. 2008. Metode Pembelajaran. Bandung: Wacana Prima. Supardi. 2011. Dasar-Dasar Ilmu Sosial. Yogyakarta: Ombak.

Puspita, a., rezki, r., hamid, s., \& hamsiah, a. Teacher professionalism and learning services to improve students'learning outcomes in pai elementary school. Lentera pendidikan: jurnal ilmu tarbiyah dan keguruan, 24(1), 106-113.

Supriatna, Nana, dkk. 2009. Pendidikan IPS di SD. Bandung: UPI Press.

Suprijono, Agus. 2012. Cooperative Learning: Teori dan Aplikasi Paikem. Yogyakarta: Pustaka Pelajar.

Susanto, Ahmad. 2014. Pengembangan Pembelajaran IPS di Sekolah Dasar. Jakarta: Kencana.

Susilana, R. 2008. Media Pembelajaran. Jakarta: Wacana Prima. 